\title{
Climatic Changes in the western part of the Chinese Loess Plateau during the Last Deglacial and the Holocene: A Synthesis of Pollen Records
}

\author{
Aizhi Sun ${ }^{a}, \quad$ Zhaodong Feng ${ }^{b, *}$ \\ ${ }^{a}$ College of Earth Sciences, University of Chinese Academy of Sciences, 19A Yuquan Road, \\ Beijing 100049, China (aizhisun@ucas.ac.cn) \\ ${ }^{\mathrm{b}}$ Xinjiang Institute of Ecology and Geography, Chinese Academy of Sciences, Urumqi \\ 830011, China (fengzd@1zu.edu.cn) \\ * Corresponding Author: Z.-D. Feng (fengzd@1zu.edu.cn)
}

\begin{abstract}
The Last Deglacial $(\sim 15,000-\sim 11,500$ cal. BP) in the western part of the Chinese Loess Plateau experienced three sub-stages of vegetation changes: a steppe period $(15,000$ to $\sim 13,600$ cal. BP), a forest-steppe period $(\sim 13,600$ to $\sim 12,400 \mathrm{cal} . \mathrm{BP})$, and again a steppe period ( 12,400 cal. BP and $\sim 11,500$ cal. BP). The Holocene climate can be divided into three stages. The Early Holocene $(\sim 11,500-\sim 7,000$ cal. BP) was the Holocene Climatic Optimum. The Middle Holocene ( 7,000- 3,000 cal. BP) was considerably drier and colder than the Early Holocene. The Late Holocene (past $~ 3000$ years) was a period of further and more dramatic climate deterioration. The pollen data documented five abrupt dry and cool events of the Early Holocene. The five abrupt events (dry and cool) were chronologically correspondent with the North Atlantic "Bond Events". To explain the climate changes during the last Deglacial and the Holocene, three mechanisms can be invoked: solar insolation, North Atlantic Deep Water (NADW), and solar activity. First, the Holocene Climatic Optimum and the drying and cooling trend of the past $\sim 7,000$ years were the delayed climatic responses to the insolation. Second, slowdown or shutdown of NADW formation resulted from ice melt-water injection into the North Atlantic Ocean during the Last Deglacial warming produced those deglacial cold events (e.g., Older Dryas and Younger Dryas). Third, the Holocene "Bond Events" were solar activity-driven, i.e., atmospheric convection shifted away from western Pacific warm pool and the Asian monsoons were thus weakened during
\end{abstract}


lower solar-activity intervals.

Keywords: Last Deglacial, Holocene, Bioclimatic Change, Palynological Study, Chinese Loess Plateau.

\section{Introduction}

The semiarid Chinese Loess Plateau is considered to be very important for Quaternary paleoclimate research because it is a region where the intensified interactions between the winter monsoon originated from high-latitudinal continent and the summer monsoon originated from low-latitudinal oceans have been the typical characteristics during the Quaternary (Feng et al., 1993, 2006a; Li et al., 1988; Liu, 1987). The prevailing westerlies might have also dominated the semiarid Chinese Loess Plateau at least during glacial times (Porter and An, 1995; Zhou et al., 1996). The intensified interactions were reported to be pronouncedly expressed as abrupt climatic events during the Last Deglacial (i.e., after the Last Glacial Maximum) and the Holocene (the past 11,500 years) (Zhou et al., 1999). These

abrupt climatic changes were documented as dry events from the low latitudinal Asian Monsoon region (Dykoski et al., 2005; Hong et al., 2003; Huang et al., 2009; Wang et al., 2001, 2005; Wang et al., 2006) and as cold events in the high latitudinal North Atlantic region (Alley, 2000; Andrews et al., 1999; Barber et al., 1999; Bond et al., 1997, 2001; Kiennast et al., 2001; McManus et al., 2004; Oppo et al., 2003). However, many differences between the North Atlantic records and the Asian Monsoon records were noted. For example, the most dramatic Holocene event occurred at $\sim 5500 \mathrm{cal}$. BP in the North Atlantic region (Bond et al., 2001; Oppo et al., 2003), while the most dramatic Holocene event occurred at 4000 cal. BP in the Asian Monsoon region (Dykoski et al., 2005; Liu and Feng, 2012; Wang et al., 2005).

Although many reconstructions of the Last Deglacial and the Holocene climatic changes have been reported (Mayewski et al., 2004; Wanner et al., 2008), the reconstructions are geographically uneven and are especially lack in some climatically sensitive regions. It is thus imperative to investigate regional responses to these short time-scale climate changes, to explore the geographic coherence of these changes, and to comprehend the controlling mechanisms in those climatically sensitive regions. The Chinese Loess Plateau is one of 
those climatically sensitive regions (An, 2000; Li et al., 1988; Shi et al., 1993).

Pollen analyses have been recently conducted to retrieve the late Pleistocene and the Holocene vegetation changes in the Chinese Loess Plateau (e.g., Feng et al., 2004, 2006a, 2006b, 2007; Li et al., 2009; Zhao et al., 2010; Zhou et al., 1999). However, most of the aforementioned records failed to provide the needed details of the bioclimatic history for the Last Deglacial and the Holocene. Two major problems are identified to have contributed to these failures: (1) inadequate chronologies (e.g., problematic methods, insufficient dates, and disturbed strata), and (2) low sampling resolution. Here, we re-analyzed and synthesized four recently published fossil pollen records from Xiaogou section (Wu et al., 2009), Haiyuan section (Sun et al., 2007), Sujiawan section (Feng et al., 2004, 2006b) and Dadiwan section (Feng et al., 2006b) within the western part of the Chinese Loess Plateau (i.e., sites 1,2,3,4 in Fig. 1) in hope that our understanding of the geographic coherency and the temporal rhythm of the Last Deglacial and Holocene abrupt climatic changes can be improved. It should be noted here that the chronology of Xiaogou section in this paper is improved over the original one (Wu et al., 2009) with newly-obtained dates and the original interpretations of those pollen data (Feng, 2004, 2006b; Sun et al., 2007) are significantly updated in this paper with our up-to-date knowledge.

\section{Study Area and Laboratory Methods}

This study focuses on the western part of the Chinese Loess Plateau. The present climate in the western part of the Chinese Loess Plateau is characterized by cold and dry winters and warm and wet summers. The mean annual temperature is $9^{\circ} \mathrm{C}$ in the southern end and gradually decreases to $4^{\circ} \mathrm{C}$ in northern end. Mean annual precipitation is $550 \mathrm{~mm}$ in southern end and gradually decreases to $250 \mathrm{~mm}$ in northern end with the potential evaporation ranging from $600 \mathrm{~mm}$ to $1000 \mathrm{~mm}$. The natural vegetation is hardly persevered due to severe human disturbances (Zhao et al., 2004). The preserved natural vegetation on high-elevation loess hills is dominated by Stipa bungeana, S. breviflora, S. grandis, S. kryocii, Thymus mongolicu, Artemisia gmelinii and A. frigida. There are small patches of secondary forests mainly consisting of Quercus liaotungensis, Pinus tabulaeformis, Populus tremula, Betula 
platyphylla, Rosa hugonis, Hippophae rhamnoides, Prinsepia uniflora and Ostryopsis. Natural forests occur exclusively in the nearby mountains (e.g., Huajialing Ridges, Liupan Mountains, Quwu Mountains, and Nanhua Mountains) where effective soil moisture is higher than the surrounding low-elevation loess terrains (Huang, 1997; Wu, 1980).

Pollen analysis is commonly adopted to reconstruct past bioclimatic changes and the method is based on the assumption that the past vegetation composition was dependent on the past climatic condition. Our interpretation of the fossil pollen records relied on the published descriptions of modern pollen-vegetation relationships from other areas in northern China where human disturbance is minimal (Herzschuh et al., 2003; Li, 1998; Li et al., 2000; Liu et al., 1999; Ma et al., 2008; Xu et al., 2007; Yu, 2001; Zhao and Herzschuh, 2009). Here, we used pollen indices to reconstruct the past bioclimatic change and the used pollen indices include main pollen types, percentage of coniferous tree pollen (as a cool or/and wet climate indicator), percentage of broadleaf tree pollen (as a warm and moist climate indicator), percentage of shrub and herb pollen percentage (as a dry climate indicator), and total pollen concentration (normally as a pollen production indicator or sometime as an indicator of vegetation density) (Chen et al., 2006; Feng et al., 2006b; Ran and Feng, 2013; Shen et al., 2005; Sun and Feng, 2013; Wang and Feng, 2013; Zhao et al., 2010).

For palynological study, pollen samples were first treated with $\mathrm{HCl}(5-10 \%)$ and $\mathrm{HF}$ (36\%). The treatment was followed by sieving in ultrasonic bath and mounting in glycerine. Exotic Lycopodium tables were added for calculation of pollen concentration (Moore et al., 1991). More than 75 types of fossil pollen were identified from all samples and more than 300 pollen grains (not including spores) were counted for each one of the samples. When pollen was relatively sparse in a sample, about 200 grains were counted. Our pollen identification is based on the published pollen keys and on also on our pollen-slide collection of more than 200 plant species from northern China. The percentage of each pollen type was calculated based on the sum of all counted pollen grains and are plotted against age using Grapher 2.0 (Duane et al., 1990). 


\section{Chron-stratigraphies and Pollen Data}

\subsection{Xiaogou section}

\subsubsection{Chrono-stratigraphy}

Xiaogou (XG) section $\left(36.02^{\circ} \mathrm{N}, 104.99^{\circ} \mathrm{E} ; 1625 \mathrm{~m}\right.$ a.s.l.), a lacustrine-fluvial-eolian complex covering the depositional history of the last $\sim 30,000$ years (Fig. 2), is a natural exposure on the first terrace of Zuli River (a branch of the Yellow River) with a total thickness of $4000 \mathrm{~cm}$. The lacustrine-fluvial portion $(4000-256 \mathrm{~cm})$ was formed at the outlet of the Zuli River under a closed terminal lake condition when the Zuli River was completely dammed by a massive landslide during the period between $\sim 30,000$ and $\sim 4,000 \mathrm{cal}$. BP. The top portion $(256-0 \mathrm{~cm})$ is of eolian origin and was deposited during the past $\sim 4,000$ years (Wu et al., 2009). Our discussion in this paper focuses only on the portion that covers the past $\sim 15,000$ years (i.e., top $\sim 2900 \mathrm{~cm}$ of the section).

Thirteen (13) charcoal samples were AMS dated and seven (7) organic-rich bulk samples were conventionally dated (Table 1). It should be particularly mentioned that we were frustrated by eight similar dates (around $10,000{ }^{14} \mathrm{C}$ BP) within 10-m thick sediment $(1600-2600 \mathrm{~cm})$ and we tentatively attributed these nearly constant dates to the atmospheric $\delta^{14} \mathrm{C}$ instability at $\sim 10,000{ }^{14} \mathrm{C}$ BP (see Hughen et al., 1998). We established an age-depth model by using a polynomial regression method based on 20 calibrated dates. The age-depth model is expressed as: Age $=(1 \mathrm{E}-06) \mathrm{X} \mathrm{Depth}^{3}-0.004 \mathrm{X}$ Depth $^{2}+12.12 \mathrm{X}$ Depth $\left(\mathrm{R}^{2}=0.809\right)$.

\subsubsection{Pollen data}

Sampling intervals at Xiaogou (XG) section were 3-8 $\mathrm{cm}$ and seven bioclimate phases can be reconstructed based on seven pollen assemblage zones (Fig. 2).

XGZ-1 ( 15,000 to $\sim 13,600$ cal. BP; 2900-2686 cm): The pollen assemblage is dominated by a relative high percentage of coniferous pollen with a lower pollen concentration (mean= 2500 grains/g). It has merely detectable broadleaf tree and shrub pollen with a low percentage of herb pollen. The assemblage suggests that a desert steppe occupied the landscape under a cold and dry climate within the Zuli River basin. 
XGZ-2 ( 13,600 to $\sim 12,400$ cal. BP; 2686-2445 cm): The assemblage is characterized by a sudden appearance of some broadleaf trees and shrubs (e.g., Quercus, Betula, Ephedra) and also by a significant increase of some herbs (e.g., Artemisia, Polygonum, Plumbaginaceae and Stellera). The assemblage and the dramatically increased pollen concentration seem to suggest that the desert steppe of XGZ-1 was replaced by forest-steppe vegetation under a milder and wetter climate.

XGZ-3 ( 12,400 to $\sim 11,500$ cal. BP; $2445-2210 \mathrm{~cm})$ : Two distinguishable features are observable in the pollen assemblage: (1) a dramatic decrease in pollen concentration (mean= 1250 grains/g), and (2) nearly complete disappearance of broadleaf trees (e.g., Quercus, Betula, Ulmus). These two features suggest that the forest-steppe of XGZ-2 was deteriorated to a dry steppe under a colder and drier climate and that the coniferous forests or coniferous tree patches in higher elevations shrank in response to the deteriorated climate.

XGZ-4 ( 11,500 to $\sim 6,800 \mathrm{cal}$. BP; $2210-770 \mathrm{~cm})$ : This pollen zone is typified by drastic increases in pollen concentration (mean $=\sim 4500$ grains/g) and in broadleaf tree pollen percentage at the expenses of coniferous and herb components. It suggests that a forest-steppe vegetation of XGZ-4 replaced the dry steppe of XGZ-3 under a warmer and wetter climate. It is noticeable that the Poaceae and Chenopodiaceae pollen percentages are considerably higher than those in XGZ-3, indicating that the area (i.e., the Zuli River basin) was probably within (or adjacent to) the northern (i.e., drier) margin of a forest steppe. It is also noticeable that several cool and dry events are well marked by significantly lowered pollen concentration and also by dramatically dropped broadleaf tree pollen percentage.

XGZ-5 ( 6,800 to $\sim 5,600 \mathrm{cal}$. BP; 770-578 $\mathrm{cm})$ : The assemblage is characterized by a dramatic decrease in pollen concentration (mean $=\sim 1800$ grains/g) and nearly complete disappearance of broadleaf trees, accompanied by significant increases in herb component (e.g., Artemisia, Chenopodiaceae, Compositae, and Poaceae). The assemblage suggests that a steppe dominated the landscape under a relatively cold and dry climate. The relatively and variably high percentage of coniferous component (especially Tsuga pollen) indicates that coniferous tree patches existed in the relatively moist shady slopes (i.e., north-facing slopes) of higher elevations (e.g., Huajialing Ridges).

XGZ-6 ( 5,600 to $\sim 3,600 \mathrm{cal}$. BP; $578-330 \mathrm{~cm})$ : The pollen zone is characterized by four 
features: (1) a moderate increase in pollen concentration, (2) a slight increase in coniferous tree pollen percentage(especially Tsuga pollen), (3) a noticeable decrease in herb pollen percentage, and (4) merely detectable broadleaf tree pollen. This assemblage is interpreted to represent improved vegetation under an improved moisture condition after a steppe-dominated period of XGZ-5.

XGZ-7 ( 3,600 to $\sim 0$ cal. BP; 330-0 cm): This zone is marked by a significant increase in herb component (e.g., Artemisia, Chenopodiaceae, Compositae, Poaceae, Polygonum, Polemonium, and Stellera) at the expense of the coniferous tree component. Its pollen concentration is extremely low and broadleaf tree pollen is almost absent from the pollen spectra. The assemblage suggests that the steppe vegetation of XGZ-6 was further deteriorated since $\sim 3,600$ cal. BP and that the studied site was probably within the northern (drier) margin of a steppe.

\subsection{Haiyuan section}

\subsubsection{Chrono-stratigraphy}

Haiyuan (HY) section $\left(36.43^{\circ} \mathrm{N}, 105.99^{\circ} \mathrm{E} ; 1600 \mathrm{~m}\right.$ a.s.l.) is an $850-\mathrm{cm}$ thick natural exposure on the first terrace of Qingshui River (also a branch of the Yellows River) and covers the depositional history of the Last Deglacial and the early Holocene from 14,000 to 7,400 cal. BP (Sun et al., 2007). This section consists of eight stratigraphical units from the bottom to the top (Fig. 3). The first $(850-750 \mathrm{~cm})$ and third $(580-380 \mathrm{~cm})$ units are gray-yellowish fluvial loess layers. The second unit $(750-580 \mathrm{~cm})$, a dark-grayish clay layer, is distinctively characterized by readily observable powdery carbonate, half-decomposed organic matter (plant litter) and snail shells. The fourth $(380-360 \mathrm{~cm})$ and sixth units $(250-220 \mathrm{~cm})$ are dark-grayish silty clay layers. The fifth unit $(360-250 \mathrm{~cm})$ is an aeolian loess layer and the seventh unit $(220-65 \mathrm{~cm})$ is a strongly pedogenical-altered aeolian-fluvial complex. The top $65 \mathrm{~cm}$ is fluvially-altered minor paleosol.

We obtained 9 AMS ${ }^{14} \mathrm{C}$ dates on organic-rich samples (Table 2). The age-depth model was established using a polynomial regression method. The age-depth model is expressed as: Age $=(5.734 \mathrm{E}-03) \times$ Depth $^{2}+(1.263 \mathrm{E}+01) \mathrm{X}$ Depth $+(7.396 \mathrm{E}+03)\left(\mathrm{R}^{2}=0.9724\right)$. The 
extrapolated age of the bottom $(850 \mathrm{~cm})$ is $\sim 14,000 \mathrm{cal}$. BP and the extrapolated age of the top $(0 \mathrm{~cm})$ is $\sim 7,400 \mathrm{cal}$. BP.

\subsubsection{Pollen data}

Sampling intervals at Haiyuan (HY) section were $5 \mathrm{~cm}$ in the lower $(850-760 \mathrm{~cm})$ and upper $(580-00 \mathrm{~cm})$ portions and $2 \mathrm{~cm}$ in the middle portion $(760-580 \mathrm{~cm})$ and six bioclimate phases were reconstructed based on six pollen assemblage zones (Fig. 3).

HYZ-1 ( 14,000 to $\sim 13,700$ cal. BP; $850-760 \mathrm{~cm})$ : The pollen assemblage is absolutely dominated by herb pollen (e.g., Artemisia, Chenopodiaceae, Poaceae). The percentages of coniferous tree and broadleaf tree components are rather low. The assemblage probably represents a steppe landscape under a relatively dry condition.

HYZ-2 $(\sim 13,700$ to $\sim 12,800$ cal. BP; $760-580 \mathrm{~cm})$ : The assemblage is distinctively characterized by the highest percentage of coniferous tree pollen (e.g., Pinus, Picea, Tsuga, Cupressaceae) of the entire section at the expense of the percentage of herb pollen. The pollen concentration is averagely high and fluctuates drastically. This assemblage suggests that a coniferous forest might have expanded extensively at least in high elevation mountains (e.g., Quwu Mountains) near the studied site. This assemblage suggests that the climatic humidity or effective soil moisture was greatly improved over the previous period (i.e., HYZ-1).

HYZ-3 ( 12,800 to $\sim 11,600$ cal. BP; 580-410 cm): The assemblage is somewhat similar to HYZ-1 in that the percentages of herb pollen (e.g., Chenopodiaceae, Artemisia, Poaceae, Compositae) increases drastically at the expenses of the percentage of coniferous pollen. It is quite noticeable that the percentage of drought-tolerated Chenopodiaceae pollen reaches the highest value of the entire section and that the pollen concentration is considerably lower than the immediate preceding period (i.e., HYZ-2). This assemblage suggests that the landscape was occupied by a Chenopodiaceae-dominated steppe under a dry climatic condition.

HYZ-4 ( 11,600 to $\sim 10,600$ cal. BP; 410-295 cm): This pollen zone is marked by a noticeable increase in the percentage of coniferous component (e.g., Pinus, Picea) at the expenses of herb component (e.g., Poaceae, Artemisia, Compositae, Chenopodiaceae). It is 
also notable that the pollen concentration and the percentage of broadleaf tree component are averagely higher than those of the immediate preceding period (i.e., HYZ-3). The pollen assemblage is interpreted to represent an overall forest-steppe landscape. However, a wetter and probably also cold event at $\sim 11,300 \mathrm{cal}$. BP is well indicated by a high peak of the pollen concentration and also by a high peak of the percentage of coniferous tree pollen. In comparison, the immediate preceding interval between $\sim 11,500$ and $\sim 11,400 \mathrm{cal}$. BP was drier and colder as indicated by a low pollen concentration and by a low percentage of broadleaf tree pollen. The immediate following interval between $\sim 11,200$ and $\sim 11,000$ cal. $\mathrm{BP}$ was probably drier and warmer as indicated by a low pollen concentration and a relatively high percentage of broadleaf tree pollen.

HYZ-5 ( 10,600 to $\sim 8,100$ cal. BP; 295-60 cm): This pollen zone is characterized by a very low pollen concentration and also by a relatively high percentage of herb pollen (e.g., Poaceae, Artemisia, Compositae, Chenopodiaceae). Two other noticeable features are: (1) the percentage of Ulmus pollen is the highest (up to 10\%) of the entire section, and (2) the percentage of Cupressaceae is constantly higher than the immediate preceding period (HYZ-4) and also than the immediate following period (HYZ-6). We interpret this assemblage to represent a sparsely-vegetated woodland landscape under a relatively warm and dry climate condition. It is also noticeable that dramatic variations in the percentage of broadleaf tree pollen, as well as the pollen concentration, seem to indicate four cool and dry spells.

HYZ-6 $(\sim 8,100$ to $\sim 7,400$ cal. BP; $60-0 \mathrm{~cm})$ : A relatively high percentage of coniferous pollen (e.g., Pinus, Picea, Tsuga) and an increased pollen concentration characterize this zone. The pollen assemblage reflects a forest-steppe landscape under a relatively warm and wet climatic condition.

\subsection{Sujiawan section}

\subsubsection{Chrono-stratigraphy}

Sujiawan (SJW) section $\left(35.53^{\circ} \mathrm{N}, 104.52^{\circ} \mathrm{E} ; 1950 \mathrm{~m}\right.$ a.s.l.) is a $450-\mathrm{cm}$ thick natural exposure on the first terrace of Guanchuan River (a branch of the Zuli River). This section covers the depositional history of the past $\sim 14,500$ years (Fig. 4) and consists of three complexes: a lower fluvial loess unit $(450-410 \mathrm{~cm})$, a middle wetland-swamp complex 
(410-305 cm) and an upper loess-paleosol complex $(305-0 \mathrm{~cm})$. The middle complex is a grayish-blue clayey silt unit and aquatic mollusks comprise much of the layer. The upper loess-soil complex contains three minor paleosols interbedded with three loess units (Feng et al., 2004, 2006b).

We obtained 8 AMS ${ }^{14} \mathrm{C}$ dates (one on bone, five on charcoals, and two on organic-rich bulk samples) (Table 3) and all dates are in a perfect order (Fig. 4). The age-depth model was established using a polynomial regression method. The model is expressed as: Age $=$ (4.393E-04) X Depth ${ }^{3}-(2.040 E-01) X$ Depth $^{2}+(3.502 E+01) X$ Depth $\left(R^{2}=0.9970\right)$ and the extrapolated age of the bottom $(450 \mathrm{~cm})$ is $\sim 14,500$ cal. BP (Fig. 4). It should be particularly mentioned that four charcoal AMS dates well define the period of the middle wetland-swamp complex $(410-305 \mathrm{~cm})$ deposition. That is, the complex was formed between 8,880 and 3,800

${ }^{14} \mathrm{C}$ BP (i.e., between 10,100 and 4,200 cal. BP).

\subsubsection{Pollen data}

Pollen samples at Sujiawan (SJW) section were taken at 5-cm intervals from the depths between $400 \mathrm{~cm}$ and $50 \mathrm{~cm}$ with the topmost $50 \mathrm{~cm}$ being sampled at $10-\mathrm{cm}$ intervals and six bioclimate phases were reconstructed based on six pollen assemblage zones (Fig. 4).

SJWZ-1 ( 14,500 to $\sim 13,400$ cal. BP; 450-435 cm): This pollen zone is marked by an extremely low pollen concentration and also by a high pollen percentage of herbs (e.g., Compositae, Artemisia, Poaceae). It is also noticeable that the percentage of Ulmus-dominated broadleaf tree pollen is high. The assemblage is interpreted to represent a desert-steppe landscape probably with patches of Ulmus-dominated woodland.

SJWZ-2 ( 13,400 to $\sim 11,600 \mathrm{cal}$. BP; 435-420 cm): The most distinctive characteristics are the increasing trend of Pinus and the accompanied decreasing trend of Compositae. Two other noticeable features are: (1) a low pollen concentration, and (2) disappearance of broadleaf tree pollen. We interpreted this assemblage to represent a desert steppe landscape under a cold and dry condition. The Pinus pollen grains were probably transported from nearby mountains (e.g., Huajialing Ridges) to the Zuli River basin where the Sujiawan section is situated. 
SJWZ-3 ( 11,600 to 5,600 cal. BP; 420-340 cm): Coniferous tree component (e.g., Pinus, Picea and Tsuga) dominates this pollen zone and the percentage of broadleaf tree pollen (e.g., Ulmus, Betula, Quercus, Juglans) is moderately high. It is quite notable that both the pollen concentration and the percentages of tree components (both broadleaf and coniferous) reach the highest of the entire section, suggesting the existence of a temperate forest in hydrologically wet flat valleys or/and in climatically wet nearby highlands probably under a wet and warm climate.

SJWZ-4 ( 5,600 to $\sim 4,500$ cal. BP; 340-315 cm): This pollen assemblage is marked by the highest herb pollen percentage of the entire section (mainly Artemisia and Compositae). Accompanied are the decreases in the percentages of tree pollen (both coniferous and broadleaf) and in the pollen concentration. The assemblage represents a dry steppe landscape under a cold and dry climate.

SJWZ-5 ( 4,500 to $~ 2,900 \mathrm{cal}$. BP; $315-250 \mathrm{~cm})$ : The percentages of coniferous tree and broadleaf tree pollen (e.g., Pinus, Abies, Ulmus, Quercus) increased over the immediate preceding period (i.e., SJWZ-4) at the expenses of the percentage of herb pollen. It is also notable that the pollen percentages of Poaceae and Chenopodiaceae also increased markedly over the immediate preceding period (i.e., SJWZ-4). We interpreted this assemblage to represent a slight amelioration of vegetation from the dry steppe of SJWZ-4 to a humid steppe of SJWZ-5 with woodland patches under a slightly ameliorated climate.

SJWZ-6 ( 2,900 to $\sim 0$ cal. BP; $250-0 \mathrm{~cm})$ : The percentage of Chenopodiaceae pollen and the percentage of Pinus dictate the pollen spectrum and the percentage of Chenopodiaceae pollen varies inversely with the percentage of Pinus pollen. It is quite notable that a strong peak of Chenopodiaceae pollen percentage deeply depressed the Pinus pollen percentage between $\sim 1,000$ to $\sim 500 \mathrm{cal}$. BP. The low pollen concentration and the domination of Chenopodiaceae pollen seem to indicate that a desert steppe might have dominated the landscape under a cold and dry climate.

\subsection{Dadiwan section}

\subsubsection{Chrono-stratigraphy}

Dadiwan (DDW) section $\left(35.00^{\circ} \mathrm{N}, 105.91^{\circ} \mathrm{E} ; 1471 \mathrm{~m}\right.$ a.s.l.) is a $500-\mathrm{cm}$ thick natural 
exposure on the first terrace of Qingshui River (a branch of the Yellows River). The section covers the depositional history of the last $\sim 13,000$ years (Fig. 5) and is dominated by a middle wetland-swamp-fluvial complex $(450-115 \mathrm{~cm})$ that is overlain by a surface Mollisol $(115-0 \mathrm{~cm})$ and underlain by a fluvially-altered loess unit $(500-450 \mathrm{~cm})$. The middle wetland-swamp-fluvial complex includes three sub-units: (1) a wetland-swamp-facies bottom layer $(450-355 \mathrm{~cm}),(2)$ a wetland-fluvial-facies middle layer $(355-170 \mathrm{~cm})$, and (3) a pedogenically-altered wetland-facies upper layer $(170-115 \mathrm{~cm})$. The wetland-swamp-fluvial complex (450-115 cm) is a stratigraphically traceable equivalent to the middle wetland-swamp complex (410-305 cm) of Sujiawan section (Feng et al., 2004, 2006b).

We obtained 9 AMS ${ }^{14} \mathrm{C}$ dates, 8 on charcoals and 1 on organic-rich bulk sample. As shown in Table 4, local reversals of the ${ }^{14} \mathrm{C}$ dates are quite common. For example, four charcoal dates are locally reversed in the lower portion $(285-356 \mathrm{~cm})$ of the middle wetland-swamp-fluvial complex (450-115 cm). An age reversal $\left(11,850{ }^{14} \mathrm{C} \mathrm{BP}\right.$ at $460 \mathrm{~cm}$ and $11,190{ }^{14} \mathrm{C}$ BP at $472 \mathrm{~cm}$ ) also occurs in the fluvially-altered loess unit. Our interpretation of these local age reversals is that flooding-related fluvial processes eroded older charcoals from the uplands and re-deposited them on the floodplains. To exclude the effects of those locally reversed dates on establishment of the age-depth relationships, we only used the calibrated dates of four charcoal samples that have not been subject to flooding re-transport and re-deposition. The ages of pollen-indicated events were then interpolated, and the ages of the top and the bottom of the section were extrapolated (Fig. 5). It should be noted that the middle wetland-swamp-fluvial complex $(450-115 \mathrm{~cm})$ at DDW section is bracketed by two interpolated ages: $\sim 4,150 \mathrm{cal}$. BP and $\sim 11,500 \mathrm{cal}$. BP. These two interpolated dates are consistent with the bracketing ages of the stratigraphically traceable equivalent at Sujiawan section, the middle wetland-swamp complex $(410-305 \mathrm{~cm})$ that was formed between 10,100 and 4,200 cal. BP, lending a support to the four (4) dates-based age interpolation at Dadiwan section.

\subsubsection{Pollen Data}

Pollen samples at Dadiwan (DDW) section were taken at 2-cm intervals throughout the 
entire section and five bioclimate phases were reconstructed based on five pollen assemblage zones (Fig. 5).

DDWZ-1 $(\sim 13,000$ to $\sim 12,000$ cal. BP; $500-460 \mathrm{~cm})$ : This pollen assemblage is overwhelmingly dominated by herb pollen (e.g., Artemisia, Compositae). Tree pollen percentage and pollen concentration are extremely low. The assemblage represents a desert steppe landscape under a dry and cold climatic condition.

DDWZ-2 $(\sim 12,000$ to $\sim 10,000$ cal. BP; 460-370 cm): Both the pollen concentration and the percentages of tree pollen (both coniferous and broadleaf) increased over the immediate preceding period (i.e., DDWZ-1) although herb component (e.g., Artemisia, Compositae, Chenopodiaceae) still dominates the assemblage. We interpret this assemblage to represent a humid steppe landscape under a wetter and probably also warmer climate.

DDWZ-3 ( 10,000 to $\sim 6,100$ cal. BP; $370-200 \mathrm{~cm})$ : This pollen zone is characterized by the highest pollen concentration and the highest percentages of coniferous tree pollen (e.g., Pinus, Picea, Tsuga) and broadleaf tree pollen (e.g., Quercus, Betula, Ulmus, Julgans) of the entire section. It suggests the existence of a temperate forest in hydrologically wet flat valleys or/and in climatically wet nearby highlands probably under a wet and warm climate.

DDWZ-4 ( 6,100 to 3,400 cal. BP; 200-105 cm): This zone is marked by a moderately high percentage of broadleaf tree pollen (e.g., Quercus, Betula, Ulmus) and by a relatively high percentage of coniferous tree pollen (e.g., Pinus, Tsuga, Picea) although the herb component (e.g., Poaceae, Compositae, Chenopodiaceae, Artemisia) still dominates the assemblage. Two more features need mentioning. First, the pollen concentration reaches the highest of the entire section and fluctuates dramatically. Second, the Ulmus is normally an under-represented in a pollen spectrum and the high percentage of Ulmus pollen in this zone may well indicate the existence of Ulmus-dominated tree patches or woodlands near the site. We interpreted this assemblage to represent an Ulmus-dominated forest-steppe landscape.

DDWZ-5 ( $\sim 3,400$ to $\sim 0$ cal. BP; 105-0 cm): Herb component (up to $90 \%$ ) overwhelmingly dominates the pollen spectrum (Poaceae, Chenopodiaceae, Compositae and Artemisia) at the expense of coniferous component. The percentage of broadleaf tree pollen (Ulmus, Beluta, Quercus) remains moderately high. The pollen assemblage suggests that the preceding forest steppe (i.e., DDWZ-4) deteriorated to a steppe under a dry and probably also cold climate. 


\section{Temporal Sequence of Climatic Changes}

\subsection{Dramatic climatic event of the Last Deglacial ( 15,000- 11,500 cal. BP)}

The pollen data from $\mathrm{XG}$ and $\mathrm{HY}$ sections provide much more details of the Last Deglacial climatic changes than SJW and DDW sections and the latter two records (i.e., SJW and DDW) do not have adequate temporal resolutions. XG pollen record (middle panel in Fig. 6) revealed that the regional climate during the Last Deglacial $(\sim 15,000-11,500$ cal. BP) experienced three sub-stages of vegetation changes that were chronologically correspondent with the North Atlantic deglacial sub-stages of climatic changes (Bond et al., 2001; Grootes and Stuiver, 1997). The first sub-stage $(\sim 15,000$ to $\sim 13,600 \mathrm{cal}$. BP) was a period when a steppe overwhelmingly dominated the landscape under a dry and cold condition in the western part of the Chinese Loess Plateau. The first sub-stage was chronologically correspondent with the North Atlantic Older Dryas cold event ( 14,660 to 13,580 cal. BP) retrieved from the Greenland ice core (GISP2) $\delta^{18} \mathrm{O}$ record (bottom portion of leftmost panel in Fig. 6). The second sub-stage $(\sim 13,600$ to $\sim 12,400$ cal. BP) was a period when a forest-steppe replaced the preceding steppe under a significantly ameliorated effective moisture condition. The second sub-stage was chronologically correspondent with the North Atlantic Alleröd warm interval ( 13,580 to $\sim 12,410$ cal. BP) retrieved from the Greenland ice core (GISP2) $\delta^{18} \mathrm{O}$ record. During the third sub-stage between $\sim 12,400$ cal. BP and $\sim 11,500$ cal. BP, a steppe dominated the landscape in the southern part and a desert steppe in the northern part. The third sub-stage was chronologically correspondent with the North Atlantic Younger Dryas cold epoch $(\sim 12,410$ to $\sim 11,420$ cal. BP) retrieved from the Greenland ice core (GISP2) $\delta^{18} \mathrm{O}$ record. Again, this three sub-stage pattern of the Last Deglacial is extremely well documented at XG section (middle panel in Fig. 6) and also reasonably corroborated by pollen data at HY section (right penal in Fig. 6). A lacustrine- wetland-eolian section at nearby Jingning site also documented the aforementioned three sub-stage pattern of the Last Deglacial climate change (see Feng et al., 2007). It should also be noted that similar climatic sequences have also been reported from other areas of China, e.g., from Guliya ice core (Yao et al., 1998) in the Tibetan Plateau and from Hulu Cave (Wang et al., 2001) in southern China. The stalagmite $\delta^{18} \mathrm{O}$ record from Dongge Cave (site 6 in Fig. 1 and second 
curve in Fig. 6) is by far the most reliable record of such a patter from China (Wang et al., 2005).

\subsection{Abrupt climatic events of the Early Holocene ( 11,500- 7,000 cal. BP)}

The middle portion XG section ( $2300-\sim 900 \mathrm{~cm}$ sediment) is palynologically typified by high pollen concentration and high broadleaf tree pollen percentage (middle panel of Fig. 6) and covers the depositional history of the Early Holocene spanning from $\sim 11,500$ to $\sim 7,000$ cal. BP, suggesting that wet and warm climates generally dominated the western part of the Chinese Loess Plateau during the Early Holocene. The pollen record also well documented five abrupt dry and cool events (i.e., E1,.., E5 in Fig. 6) occurred during the wet and warm Early Holocene. Each one of the five events is characterized by drastic decreases in pollen concentrations and in tree pollen percentage (especially in broadleaf tree percentage) and also by accompanied increase in herb pollen percentage. In addition, two sets of non-pollen data also well documented those five events. That is, each one of the five dry and cool events is characterized by a drastic decrease in total organic matter content and also by a drastic increase in mean grain size (i.e., TOC and Md in middle panel of Fig. 6). The five dry and cold events were centered at $\sim 11,300$ cal. BP (E1), 10,300 cal. BP (E2), 9,500 cal. BP(E3), $\sim 8,400$ cal. BP (E4), and 7,500 cal. BP (E5). It appears that the five events retrieved from XG section are reasonably corroborated by pollen data from HY section (right panel in Fig. $6)$.

It is quite notable that all of five events $(\mathrm{E} 1, \ldots, \mathrm{E} 5)$ from $\mathrm{XG}$ section are chronologically comparable with the weak-monsoon events retrieved from the well-dated stalagmite $\delta^{18} \mathrm{O}$ record of Dongge Cave (Wang et al., 2005; second curve in Fig. 6) and also from the well-dated cellulose $\delta^{13} \mathrm{C}$ record of Hongyuan Peat (Hong et al., 2003; third curve in Fig. 6 and site 5 in Fig. 1). Our XG pollen record, together with Dongge Cave record and Hongyuan Peat record, lends a strong support to the notion that the Holocene ice-rafted debris events (i.e., IRD) of the North Atlantic Ocean (Bond et al., 1997; first curve in Fig. 6) might have had a far-reaching climatic significance beyond the North Atlantic region or to the notion that those IRD events were climatologically originated from other region(s) other than from the 
North Atlantic Ocean itself (Hong et al., 2003; Oppo et al., 2003; Schmidt et al., 2012; Wang et al., 2005).

Admittedly, we are not confident yet to report any Middle and Late Holocene "abrupt events" corresponding to those North Atlantic IRD events (or Bond Events) from the aforementioned three sections (i.e., XG, SJW, and DDW). First, the top portion of DDW section (only $115 \mathrm{~cm}$ thick) covering the past $~ 4000$ years is actually well-developed Mollisol which did not contain any high-resolution climatic information at all simply due to post-depositional alteration of pedogenesis (see Feng et al., 2004). Second, the top $9 \mathrm{~m}$ of XG section covering the past $\sim 7,000$ year seems to have only expressed a weak (rather low amplitude) 450-year quasi-cycle of particle size variations (see Wu et al., 2009). Third, the upper loess-paleosol complex at Sujiawan (SJW) section (305 $\mathrm{cm}$ thick) covering the depositional history of the past $\sim 4000$ years contains three loess-paleosol couplets, seemingly implying a 1300-year quasi-cycle (see Feng et al., 2004, 2006b). Two possibilities can be offered to explain the lack of "Bond Events" during the past $~ 7,000$ years. First, the depositional environments were lack of the needed sensitivity to record those "Bond Events". Second, the "Bond Events" were not strong enough to be registered in those sequences. Apparently, more in-depth investigations are needed.

\subsection{General characteristics of the Holocene}

The relatively well-dated Holocene pollen records (i.e., XG, SJW, and DDW) from the western part of the Chinese Loess Plateau can be generally divided into three stages: (1) Early Holocene ( 11,500- 7,000 cal. BP), (2) Middle Holocene ( 7,000- 3,000 cal. BP), and (3) Late Holocene (past $\sim 3000$ years). The Early Holocene $(\sim 11,500-\sim 7,000$ cal. BP) was characterized by high pollen concentration, high pollen percentages of trees (especially broadleaf trees) and low pollen percentage of shrubs and herbs (dark-shaded zone in Fig. 7). Apparently, the Early Holocene was the Holocene Climatic Optimum. The Middle Holocene $(\sim 7,000-\sim 3,000$ cal. BP) was typified by greatly reduced pollen concentration, significantly lowered pollen percentages of trees (especially broadleaf trees) and moderately increased pollen percentage of shrubs and herbs (light-shaded zone in Fig. 7). The pollen-represented 
climate of the Middle Holocene was considerably drier and colder in comparison with the Early Holocene. A further and more dramatic climate deterioration occurred in the Late Holocene (past $\sim 3000$ years) during which the pollen concentration was further reduced, the pollen percentages of trees were further lowered, the pollen percentage of shrubs and herbs was further increased (non-shaded zone in Fig. 7).

\section{Discussion and Conclusions}

\subsection{Underlying mechanisms}

Our synthesis of pollen data from the western part of the Chinese Loess Plateau insists on lending support to our early claims that the general history of the Last Deglacial and the Holocene climate in the East Asian monsoon margin was an ocean-delayed climate history responding to solar insolation (see Feng et al., 1993, 1998, 2004, 2006a, 2006b; Liu and Feng, 2012; Ran and Feng, 2013; Sun and Feng, 2013; Wang and Feng, 2013). That is, solar insolation at $25 \sim 50^{\circ} \mathrm{N}$ started to increase around $20,000 \mathrm{cal}$. BP and reached its peak spanning from $\sim 12,000$ to $\sim 8,000$ cal. BP (Kutzbach and Gallimore, 1988). The insolation peak at $\sim 12,000-\sim 8,000 \mathrm{ka}$ might have sufficiently warmed up the low-latitude oceans to encourage the summer monsoon's northward advances at $\sim 11,000-\sim 10,000$ cal. BP (Koutavas et al., 2006). The Holocene Climatic Optimum ( 11,500- 7,000 cal. BP) in the western part of the Chinese Loess Plateau can be regarded as a result of the delayed bioclimatic response to the insolation peak $(\sim 12,000$ to $\sim 8,000$ cal. BP). The drying and cooling trend of the past $\sim 7,000$ years is rather consistent with the reported global drying or/and cooling trend (Wanner et al., 2008) that was considered to be a delayed response to the Holocene decreasing trend of the insolation. In addition, an increasing trend of ENSO activities (Rein et al., 2005) and the negative land-air feedback mechanisms (i.e., drying climate may exacerbate the dryness because less and less locally-evaporated water vapor injects into the air) might have also contributed to the drastic drying trend of the Late Holocene (Liu and Feng, 2012).

To explain the Last Deglacial dramatic bioclimatic events in the western part of the Chinese Loess Plateau (Fig. 6), such as those corresponding with Older Dryas cold event 
( 14,660- 13,580 cal. BP), Alleröd warm interval ( 13,580- 12,410 cal. BP), and Younger Dryas cold epoch $(\sim 12,410-\sim 11,420$ cal. BP), invoking the North Atlantic Deep Water (NADW) may be sufficient. That is, the Last Deglacial warming might have periodically injected sufficient amounts of ice-melt water into the North Atlantic Ocean and the North Atlantic Deep Water (NADW) formation was thus periodically slowed down or even shut down, and consequently the northern Hemisphere (including the western part of the Chinese Loess Plateau) was periodically cooled (Sutton and Hodson, 2005; Rahmstorf, 2002).

To explain the Early Holocene abrupt bioclimatic events (i.e., E1,.., E5 in Fig. 6) in the western part of the Chinese Loess Plateau that are chronologically equivalents to the "Bond Events" in the North Atlantic region, "solar forcing-facilitated ENSO" theory seems attractive. That is, the "Bond Events" might have been paced by solar activity (Bond et al., 2001) and ENSO is the leading mode of natural variability (Visbeck, 2002). The ENSO signal may have been propagated to high latitudes via the North Atlantic Oscillations (NAO) or/and via the North Pacific Oscillations (NPO) (Bond et al., 2001). In fact, the linkage between the tropical Pacific and the high northern latitudes was reasonably documented (Stott et al., 2002; Visbeck, 2002). That is, El Niño conditions in tropical Pacific correlate with cold conditions at the northern high latitudes, whereas La Niña conditions with warm conditions. Specifically, when the northern high latitudes were cold during lower solar-activity intervals (i.e., "Bond Events"), atmospheric convection shifted away from western Pacific warm pool and the Asian summer monsoons were thus weakened (Wanner et al., 2008) and the western part of the Chinese Loess Plateau was thus dried and probably also cooled (Liu and Feng, 2012).

\subsection{Conclusions}

(1) The Last Deglacial ( 15,000- 11,500 cal. BP) in the western part of the Chinese Loess Plateau experienced three sub-stages. The first sub-stage $(15,000$ to $\sim 13,600 \mathrm{cal}$. BP) was a steppe period. The second sub-stage $(\sim 13,600$ to $\sim 12,400$ cal. BP) was a forest-steppe period. The third sub-stage $(\sim 12,400$ cal. BP and $\sim 11,500$ cal. BP $)$ was again a steppe period. 
(2) The Holocene pollen records from the western part of the Chinese Loess Plateau can be divided into three stages. The Early Holocene $(\sim 10,000-\sim 7,000$ cal. BP) was the Holocene Climatic Optimum. The Middle Holocene ( 7,000- 3,000 cal. BP) was considerably drier and colder than the Early Holocene. Further and more dramatic climate deterioration occurred in the Late Holocene (past 3000 years).

(3) The high-resolution XG section documented five abrupt dry and cool events occurred during the Early Holocene. The five events were centered at 11,300 cal. BP (E1), $\sim 10,300$ cal. BP (E2), 9,500 cal. BP (E3), 8,400 cal. BP(E4), and 7,500 cal. BP (E5).

(4) To explain the Last Deglacial and the Holocene climate changes, three mechanisms can be invoked: solar insolation, North Atlantic Deep Water (NADW) formation, and solar activities. First, the Holocene Climatic Optimum ( 11,500- 7,000 cal. BP) was a result of the delayed bioclimatic response to the insolation peak $(\sim 12,000$ to $8,000 \mathrm{cal}$. BP). The drying and cooling trend of the past $\sim 7,000$ years was a delayed response to the Holocene decreasing trend of the insolation. Second, the cold events (e.g., Older Dryas and Younger Dryas) during the Last Deglacial warming were probably the responses of massive ice-melt water injections into the North Atlantic Ocean. Third, the Early Holocene abrupt dry and cool events (i.e., E1,.., E5) were solar activity-driven. That is, atmospheric convection shifted away from western Pacific warm pool (El Niño-like) and the Asian summer monsoons were thus weakened during lower solar-activity intervals.

\section{Acknowledgments}

We want to express our sincere appreciations to following colleagues who helped us in field sampling: Professor Ma Yuzhen, Professor An Chengbang, Professor Wang Weiguo, and Dr. Wu Huining. And, Professor Tang Lingyu completed a part of pollen analysis. This synthetic paper is a result of projects supported by six Chinese NSFC grants (No. U1203821L08, No. 41002058, No. 40421101, No. 40930102, No. 40671190, and No. 4002515) and three U.S. NSF grants (NSF-ESH-04-02509, NSF-BSC-06-52304, and NSF-BCS-0078557).

\section{References}


Alley, R.B., 2000. Ice-core evidence of abrupt climate changes. PNAS 97, 1331-1334.

An, Z.S., 2000. The history and variability of the East Asian paleomonsoon climate. Quaternary Science Reviews 19, 171-187.

Andrews, J.T., Keigwin, L., Hall, F., Jennings, A.E., 1999. Abrupt deglaciation events and Holocene palaeoceanography from high-resolution cores, Cartwright Saddle, Labrador Shelf, Canada. Journal of Quaternary Science 14, 383-397.

Barber, D.C., Dyke, A., Hillaire-Marcel, C., Jennings, A.E., Andrews, J.T., Kerwin, M.W., Bilodeau, G., McNeely, R., Southon, J., Morehead, M.D., Gagnon, J.M ., 1999. Forcing of the cold event of 8200 years ago by catastrophic drainage of Laurentide lakes. Nature 400, 344-348.

Bond, G., Kromer, B., Beer, J., Muscheler, R., Evans, M.N., Showers, W., Hoffmann, S., Lotti-Bond, R., Hajdas, I., Bonani, G., 2001. Persistent solar influence on North Atlantic climate during the Holocene. Science 294, 2130-2136.

Bond, G., Showers, W., Cheseby, M., Lotti, R., Almasi, P., deMenocal, P., Priore, P., Cullen, I.H., Bonani, G., 1997. A pervasive millennial-scale cycle in North Atlantic Holocene and glacial climates. Science 278, 1257-1266.

Chen, F.H., Chen, B., Zhao, Y., Madson, D., 2006. Holocene environmental change inferred from high-resolution pollen records from inland lake deposits, arid China. The Holocene $1,675-1684$.

Duane, A.B., Janice, E.C., Craig, P.L., 1990. ParaGraph: graph editor support for parallel programming environment. International Journal of Parallel Programming 19, 75-110.

Dykoski, C.A., Edwards, R.L., Cheng, H., Yuan, D.X., Cai, Y., Zhang, M., Lin, Y., Qing, J., An, Z.S., Revenaugh, J., 2005. A high-resolution, absolute-dated Holocene and deglacial Asian monsoon record from Dongge Cave, China. Earth and Planetary Science Letters $233,71-86$.

Feng, Z.D., An, C.B., Tang, L.Y., Jull, A.J.T., 2004. Stratigraphic evidence of megahumid mid-Holocene climate in the western part of the Chinese Loess Plateau. Global and Planetary Changes 43, 145-155.

Feng, Z.D., Chen, F.H., Tang, L.Y., Kang, J.C., 1998. East Asian Monsoon Variations and Gobi Dynamics in Stages 3 and 4. Catena 33, 29-46.

Feng, Z.D., Tang, L.Y., Ma, Y.Z., Zhai, X.W., 2007. Vegetation and associated environmental changes during the marine isotope stage 3 in the western part of the Chinese Loess Plateau. Palaeogeography, Palaeoclimatology, Palaeoecology 246, 278-291.

Feng, Z.D., An, C.B., Wang, H.B., Zhai, X.W., 2006a. Holocene climatic and environmental changes in the arid and semiarid regions of China: A Review. The Holocene 16, 1-12.

Feng, Z.D., Tang, L.Y., Wang, H.B., Ma, Y.Z., 2006b. Holocene Vegetation Variations and the Associated Environmental Changes in the Western Part of the Chinese Loess Plateau. 
Paleogeography, Paleoclimatology, Paleoecology 241, 440-456.

Feng, Z.D., Thompson, L.G., Mosley-Thompson, E., Yao, T.D., 1993. Temporal and spatial variations of climate during the last 10,000 years. The Holocene 3, 174-180.

Grootes, P.M., Stuiver, M., 1997. Oxygen 18/16 variability in Greenland snow and ice with $10^{-3}$ - to $10^{5}$-years time resolution. Journal of Geophysical Research 102, 455-470.

Herzschuh, U., Kürschner, H., Ma, Y.Z., 2003. The surface pollen and relative pollen production of the desert vegetation of the Alashan Plateau, western Inner Mongolia. Chinese Science Bulletin 48, 1488-1493.

Hong, Y.T., Hong, B., Lin, Q.H., Zhu, Y.X., Shibata, Y., Hirota, M., Uchida, M., Leng, X.T., Jiang, H.B., Xua, H., Wang, H., Yi, L., 2003. Correlation between Indian Ocean summer monsoon and North Atlantic climate during the Holocene. Earth and Planetary Science Letters 211, 371-380.

Huang, D.S., 1997. Gansu Vegetation. Lanzhou: Gansu Science and Technology Press (in Chinese).

Huang, Y., Jiang, H., Michael, S., Karen, L.K., Li, D.L., 2009. Diatom response to changes in palaeoenvironments of the northern South China Sea during the last 15000 years. Marine Micropaleontology 72, 99-109.

Hughen, K.A., Overpeck, J.T., Lehman, S.J., Kashgarian, M., Southon, J., Peterson, L.C., Alley, R., Sigman, D.M., 1998. Deglacial changes in ocean circulation from an extended radiocarbon calibration. Nature 391, 65-68.

Kiennast, M., Steinke, S., Stattegger, K., Calvert, S.E., 2001. Synchronous tropical South China Sea SST change and Greenland warming during deglaciation. Science 291, 2131-3134.

Koutavas, A., deMenocal, P.B., Olive, G.C., Lynch-Stieglitz, J., 2006. Mid-Holocene El Nino-Southern Oscillation (ENSO) attenuation revealed by individual foraminifera in eastern tropical Pacific sediments. Geology 34, 993-996.

Kutzbach, J., Gallimore, R.G., 1988. Sensitivity of a coupled atmosphere and mixed-layer ocean model of changes in orbital forcing at $~ 9000$ B.P. Journal of Geophysical Research 93, 803-821.

Li, J.J., Feng, Z.D., Tang, L.Y., 1988. Late Quaternary monsoonal patterns in the Loess Plateau of China. Earth Surface Processes and Landforms 13, 125-135.

Li, W.Y., 1998. Quaternary Vegetation and environment of China. Beijing: Science Press (in Chinese).

Li, X.Q., Shang, X., Dodson, J., Zhou, X.Y., 2009. Holocene agriculture in the Guanzhong Basin in NW China indicated by pollen and charcoal evidence. The Holocene 19, 1213-1220.

Li, Y.Y., Zhang, X.S., Zhou, G.S., Ni, J., 2000. Quantitative relationships between vegetation 
and several pollen taxa in surface soil from North China. Chinese Science Bulletin 45, 1519-1523.

Liu, F.G., Feng, Z.D., 2012. A dramatic cultural transition at 4000 Calendar BP and its responsible climate changes in China. The Holocene 22(10), 1181-1197.

Liu, H.Y., Cui, H.T., Pott, R., Speier, M., 1999. The surface pollen of the woodland-steppe ecotone in southeastern Inner Mongolia, China. Review of Palaeobotany and Palynology 105, 237-250.

Liu, T.S.(eds.), 1987. Loess and Environments. Beijing: Ocean Press.

Ma, Y.Z., Liu, K.B., Feng, Z.D., Sang, Y.L., Wang, W., Sun, A.Z., 2008. A survey of modern pollen and vegetation along a south-north transect in Mongolia. Journal of Biogeography $35,1512-1532$.

Mayewski, P.A., Rohling, E.E., Stager, J.C., Karlen, W., Maasch, K.A., Meeker, L.D., Meyerson, E.A., Gasses, F., Kreveld, S.V., Holmgren, K., Lee-Thorp, J., Rosqvist, G., Rack, F., Staubwasser, M., Schneider, R.R., Steig, E.J., 2004. Holocene climate variability. Quaternary Research 62, 243-255.

McManus, J., Francois, R., Gherardi, J.M., Keigwin, L.D., Brown-Leger, S., 2004. Collapse and rapid resumption of Atlantic meridian circulation linked to deglacial climate changes. Nature 428, 834-837.

Moore, P.H., Webb, J.A., Collinson, M.E., 1991. Pollen Analysis (2nd). London: Blackwell Scientific Publications.

Oppo, D.W., McManus, J.E., Cullen, J.L., 2003. Deepwater variabilit in the Holocene epoch. Nature 422, 277-278.

Porter, S.C., An, Z.S., 1995. Correlation between climate events in the North Atlantic and China during the last glaciation. Nature 375, 305-308.

Rahmstorf, S., 2002. Ocean circulation and climate during the past 120,000 years. Nature 419, 207-214

Ran, M., Feng, Z.D., 2013. Holocene moisture variations across China and driving mechanisms: a synthesis of climatic records. Quaternary International 313/314, 179-193.

Rein, B., Luckge, A., Reinhardt, L., Sirocko, F., Wolf, A., Dullo, W.C., 2005. El Nino variability off Peru during the last 20,000 years. Paleoceanography 20, PA4003. doi:10.1029/2004PA001099.

Schmidt, M.W., Weinlein, W.A., Marcantonio, F., Lynch-Stieglitz, J., 2012. Solar forcing of Florida Straits surface salinity during the early Holocene. Paleoceanography 27(3). doi: 10.1029/2012PA002284.

Shen, J., Liu, X.Q., Wang, S.M., Matsumoto, R., 2005. Palaeoclimatic changes in the Qinghai lake are during the last 18,000 years. Quaternary International 136, 131-140.

Shi, Y.F., Kong, Z.C., Wang, S.M., Tang, L.Y., Wang, F.B., Yao, T.D., Zhao, X.T., Zhang, 
P.Y., Shi, S.H., 1993. Mid-Holocene climates and environments in China. Global and Planetary Change 7, 219-233.

Stott, L., Poulsen, C., Lund, S., Thunell, R., 2002. Super ENSO and global climate oscillations at millennial time scales. Science 297, 222-226.

Sun, A.Z., Ma, Y.Z., Feng, Z.D., Li, F., Wu, H.N., 2007. Pollen-recorded climate changes between 13.0 and 7.0 C-14 ka BP in southern Ningxia, China. Chinese Scientific Bulletin 52, 1080-1088.

Sun, A.Z., Feng, Z.D., 2013. Pollen-recorded bioclimatic variations of the last 15,000 years retrieved from Lake Qigai Nuur in the southern Mongolian Plateau of China. The Holocene 23, 1391-1402.

Sutton, R.T., Hodson, D.L., 2005. Atlantic Ocean forcing of North American and European summer climate. Science 309, 115-118.

Visbeck, M., 2002. The ocean's role in Atlantic climate variability. Science 297, 2223-2224.

Wang, Y., Zhao, Z.Z., Qiao, Y.S., Wang, S.B., Li, C.Z., Song, L.F., 2006. Paleoclimatic and paleoenvironmental evolution since the late glacial epoch as recorded by sporopollen from the Hongyuan peat section on the Zoigê Plateau, northern Sichuan, China. Geological Bulletin of China 25, 827-832 (in Chinese).

Wang, W., Feng, Z.D., 2013. Holocene moisture evolution across the Mongolian Plateau and its surrounding areas: A synthesis of climatic records. Earth-Science Reviews 122, 38-57.

Wang, Y.J., Cheng, H., Edwards, R.L., An, Z.S., Wu, J.Y., Shen, C.C., Dorale, J.A. 2001. A high-resolution absolute-dated late Pleistocene Monsoon record from Hulu Cave, China. Science 294, 2345-2348.

Wang, Y.J., Cheng, H., Edwards, R.L., He, Y.Q., Kong, X.G., An, Z.S., Wu, J.Y., Kelly, M.J., Dykoski, A.D., Li, X.D., 2005. The Holocene Asian monsoon: link to solar changes and North Atlantic climate. Science 308, 854-857.

Wanner, H., Beer, J., Butikofer, J., Crowley, T.J., Cubasch, U., Fluckige, J., Goosse, H., Grosjean, M., Joos, F., Kaplan, J.O., Kuttel, M., Muller, S.A., Prentice, L.C., Solomina, O., Stocker, T.F., Tarasov, P., Wagner, M.,Widmann, M., 2008. Mid- to Late Holocene climate change: an overview. Quaternary Science Reviews 27, 1791-1828.

Wu, H.N., Ma, Y.Z., Feng, Z.D., Sun, A.Z., Zhang, C.J., Li, F., Kuang, J., 2009. A high resolution record of vegetation and environmental variation through the last $\sim 25,000$ years in the western part of the Chinese Loess Plateau. Palaeogeography, Palaeoclimatology, Palaeoecology 273, 191-199.

Wu, Z.Y., 1980. China Vegetation. Beijing: Science Press (in Chinese).

Xu, Q.H., Li, Y.C., Yang, X.L., Zheng, Z.H., 2007. Quantitative relationship between pollen and vegetation in northern China. Science in China (Series D) 50, 582-599.

Yao, T.D., Thompson, L.G., Shi, Y.F., 1998. Climate variation since the last interglacial 
recorded in the Guliya ice core. Science in China (Series D) 40, 662-668.

Yu, G., 2001. Modern pollen samples from alpine vegetation on the Tibetan Plateau. Global Ecology and Biogeography 10, 503-519.

Zhao, C.Y., Nan, Z.R., Feng, Z.D., 2004. GIS-assisted modeling of the potential eco-hydrologic conditions in the western part of the Chinese Loess Plateau. Journal of Arid Environments 58, 387-403.

Zhao, Y., Chen, F.H., Zhou, A.F., Yu, Z.C., Zhang, K., 2010. Vegetation history, climate change and human activities over the last 6200 years on the Liupan Mountains in the southwestern Loess Plateau in central China. Palaeogeography, Palaeoclimatology, Palaeoecology 193, 197-205.

Zhao, Y., Herzschuh, U., 2009. Modern pollen representation of source vegetation in the Qaidan Basin and the surrounding mountains, north-eastern Tibetan Plateau. Vegetation History and Archaeobotany 18, 245-260.

Zhou, W.J., Head, M.J., Lu, X.F., An, Z.S., Jull, A.J.T., Donahue, D., 1999. Teleconnection of climate events between East Asian and polar, high latitude area during the last deglaciation. Palaeogeography, Palaeoclimatology, Palaeoecology 152, 163-172.

Zhou, W.J., Donahue, D.J., Porter, S.C., Jull, T.A., Li, X.Q., Stuiver, M., An, Z.S., Matsumoto, E., Dong, G.R., 1996. Variability of monsoon climate in East Asia at the end of the last glaciation. Quaternary Research 46, 219-229. 
Figure Captions

Figure 1. Map of China and its climatic contexts. Four investigated sites are: 1. Xiaogou (XG); 2. Haiyuan (HY); 3. Sujiawan (SJW); and 4. Dadiwan DDW). Two referred sites: 5. Hongyuan Peat (Hong et al., 2003, Wang et al., 2006) and 6. Dongge Cave (Dykoski et al., 2005; Wang et al., 2005).

Figure 2. Stratigraphy, age-depth model (cal. yr BP), and pollen spectra of Xiaogou (XG) section.

Figure 3. Stratigraphy, age-depth model (cal. yr BP), and pollen spectra of Haiyuan (HY) section.

Figure 4. Stratigraphy, age-depth model (cal. yr BP), and pollen spectra of the Sujiawan (SJW) section.

Figure 5. Stratigraphy, age-depth model (cal. yr BP), and pollen spectra of the Dadiwan (DDW) section.

Figure 6. Holocene pollen proxy sequences of three sections (XG, SJW, and DDW). The pollen proxy sequences can be palynologically divided into three stages: (1) Early Holocene ( 11,500- 7,000 cal. yr BP), (2) Middle Holocene ( 7,000- 3,000 cal. yr BP), and (3) Late Holocene (past 3,000 years).

Figure 7. Key pollen proxies from XG section (middle panel) and HY section (right panel) and the comparison with other well-publicized sequences. The sequences include: (1) ice-rafted debris record (IRD) from the North Atlantic (Bond et al., 1997), (2) $\delta^{18} \mathrm{O}$ record from the Greenland GISP2 ice core (Grootes and Stuiver, 1997), (3) $\delta^{18} \mathrm{O}$ record from Dongge Cave stalagmite D4 (Wang et al., 2005; Dykoski et al., 2005), and (4) $\delta^{13} \mathrm{C}$ record of peat cellulose from Hongyuan Peat (Hong et al., 2003). The gray bars mark "abrupt events" occurred in the Early Holocene (note: ka = thousand years ago). 
Figure 1

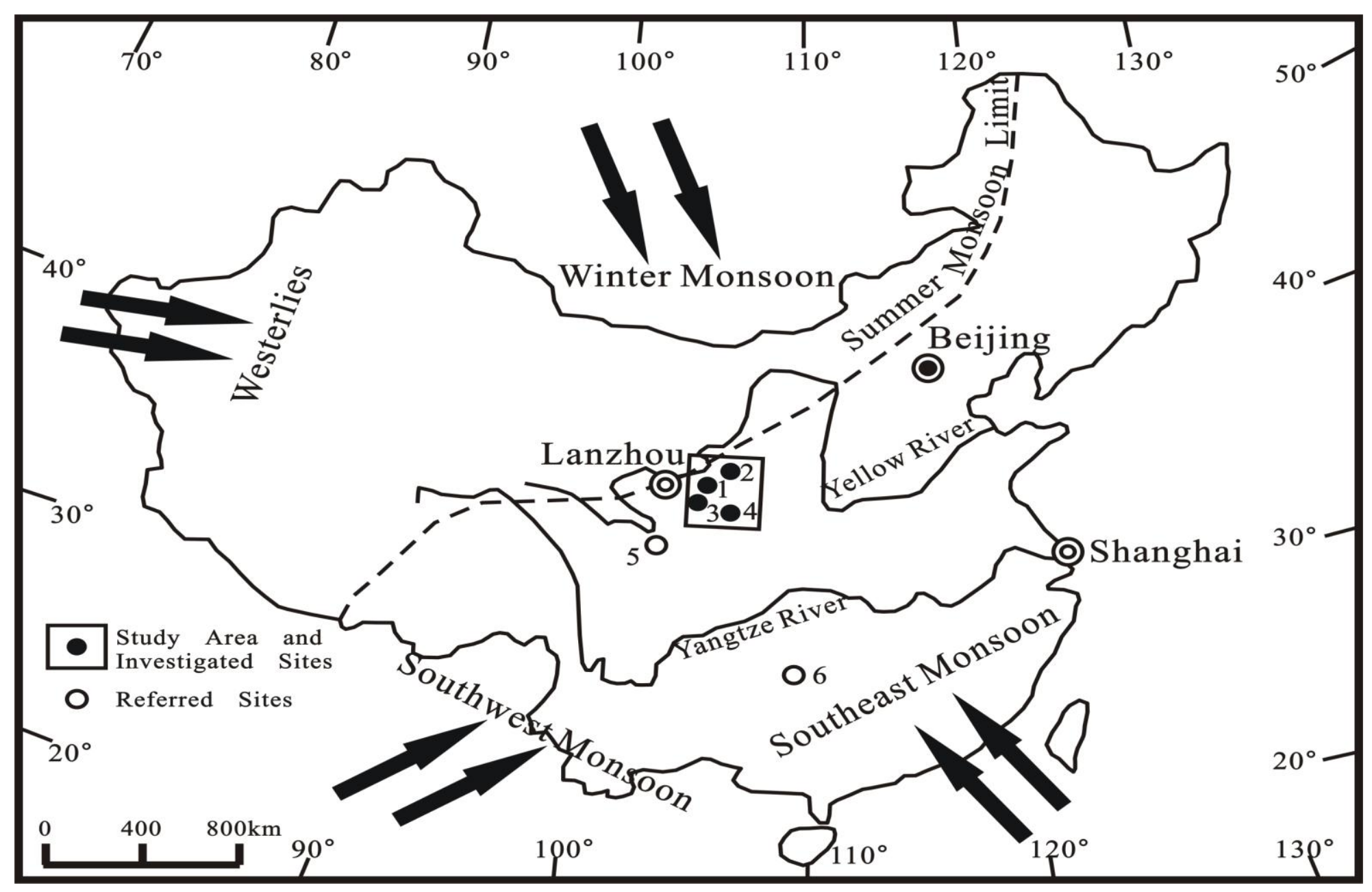


Figure 2

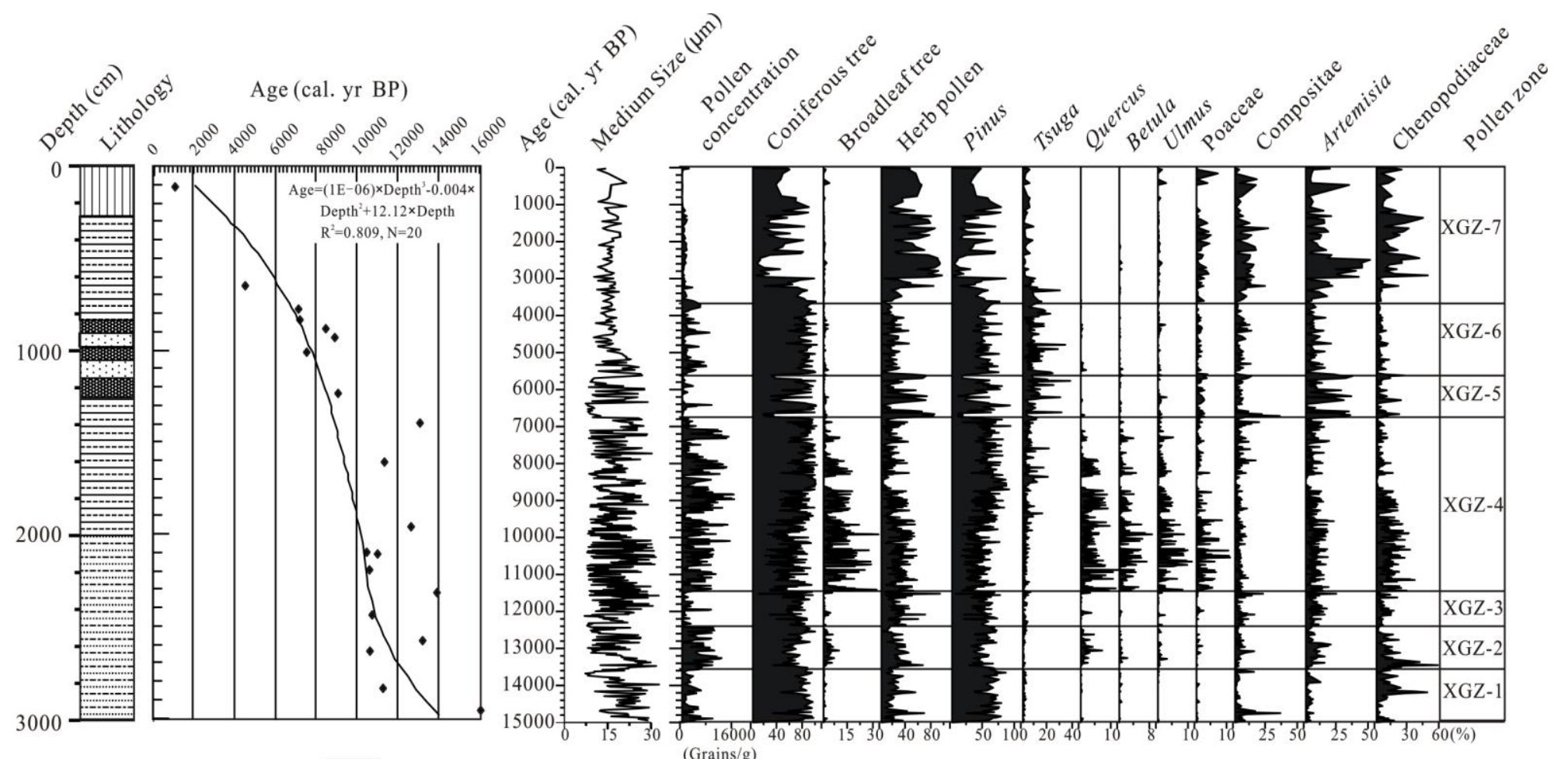

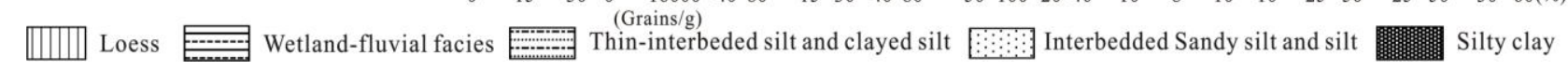


Figure 3

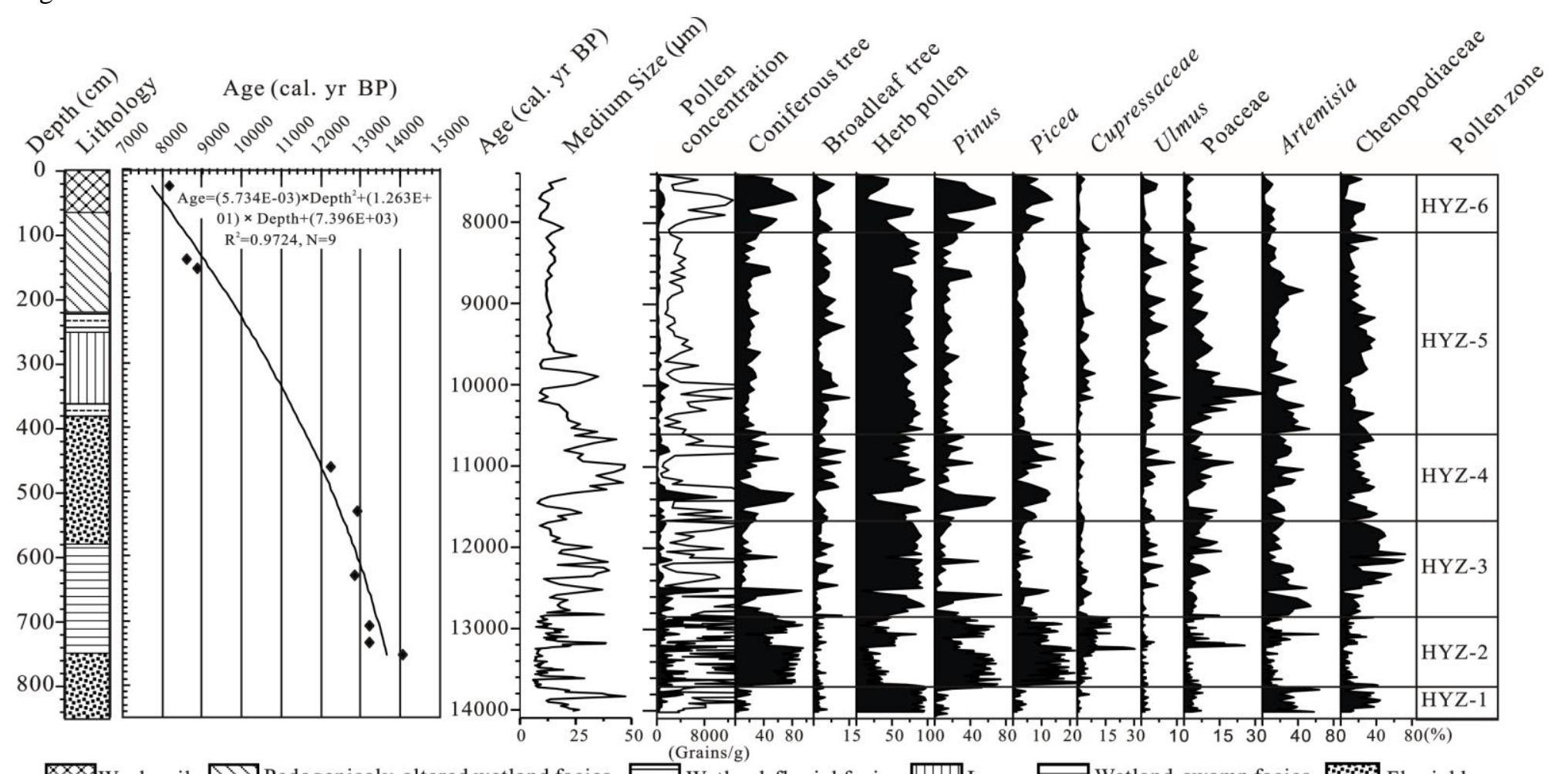

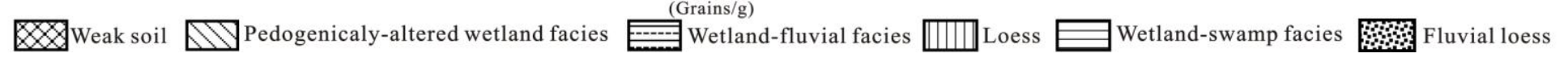




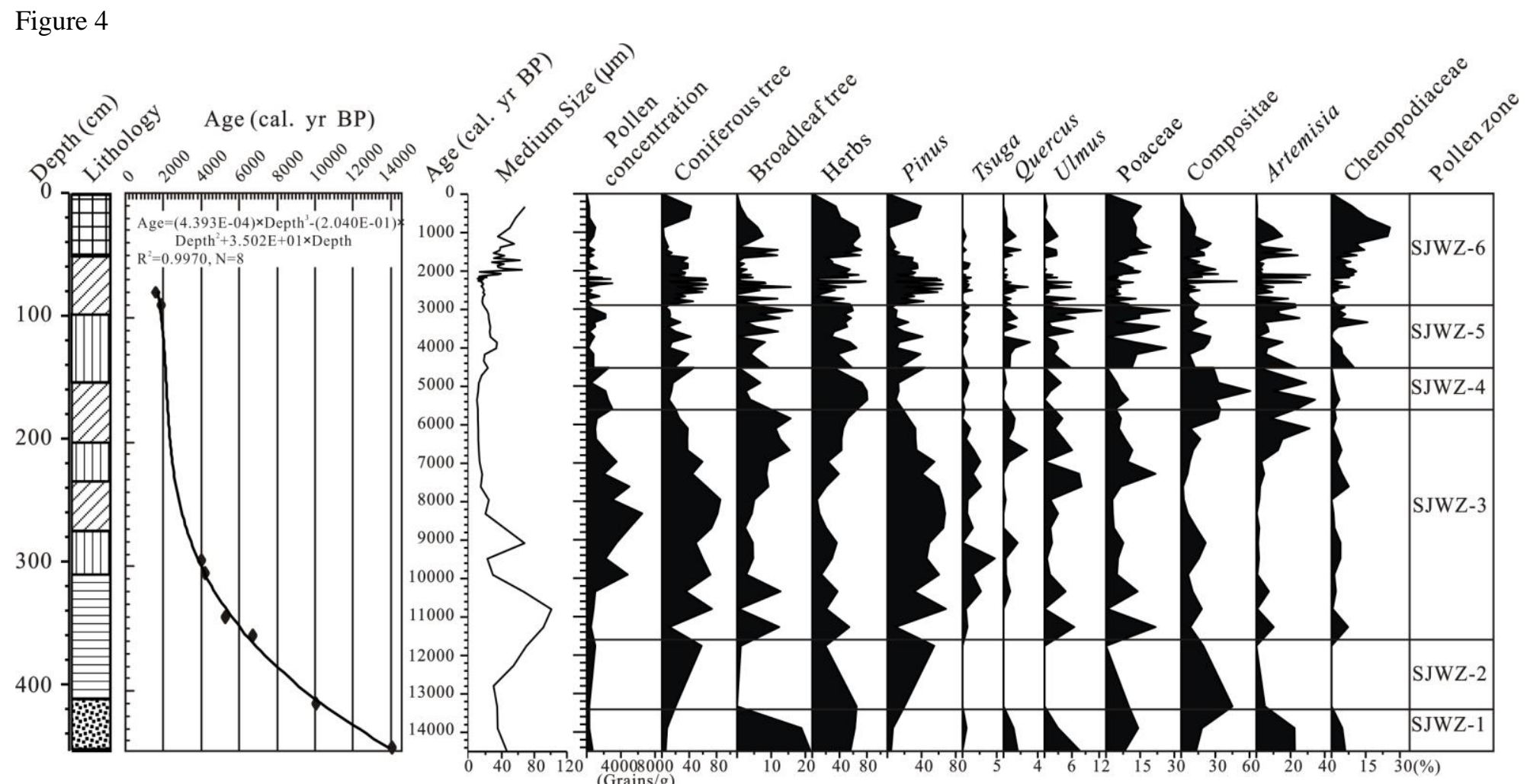

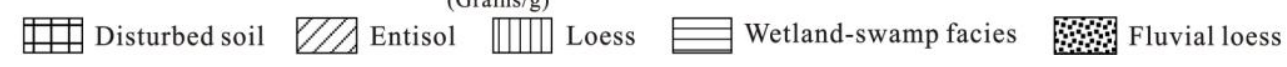




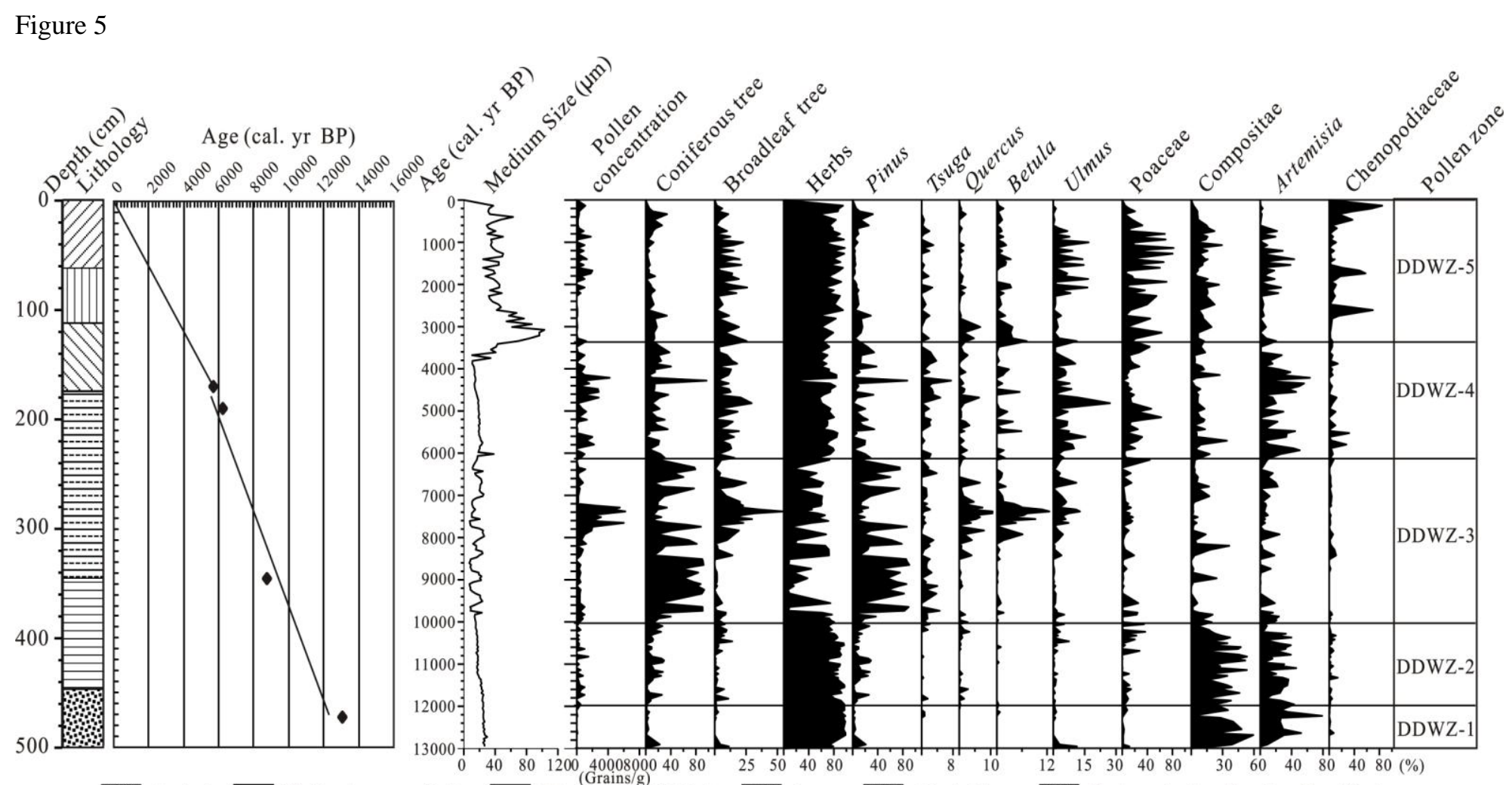

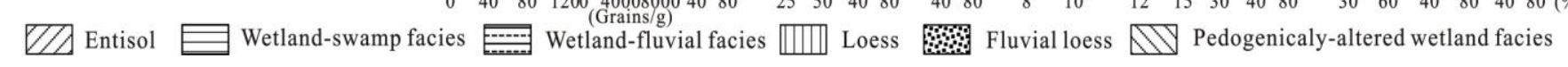


Figure 6

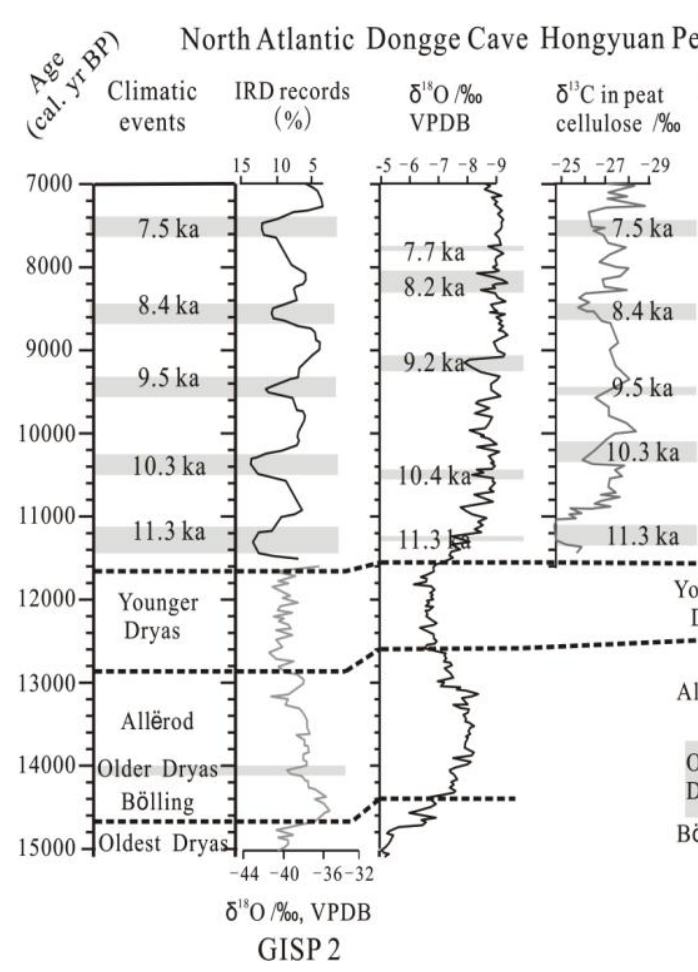

GISP 2
XG section

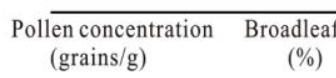

HY section Pollen concentration
(grains $/ \mathrm{g})$$\underset{\text { Broadleaf tree }}{(\%)}$

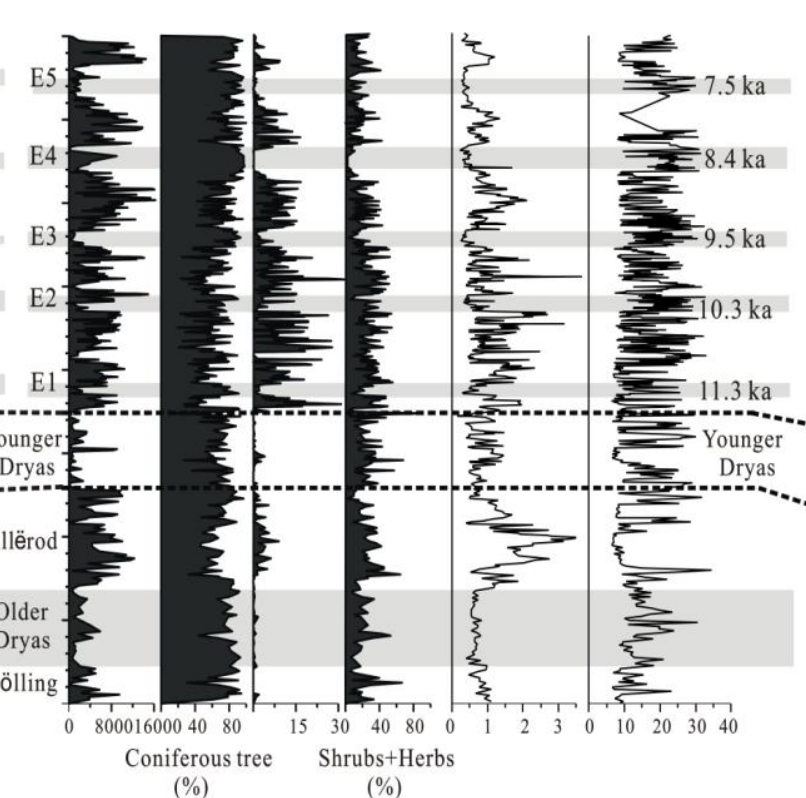

(\%)

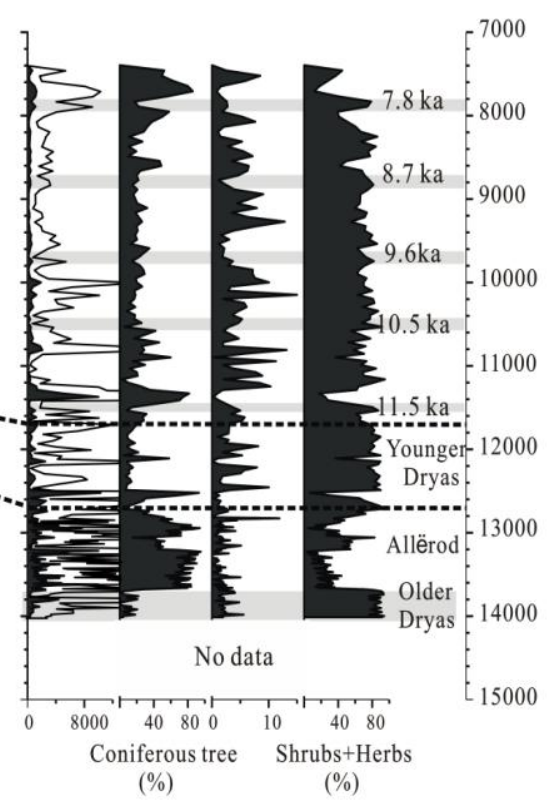

(\%)

$\%)$

(1) 
Figure 7

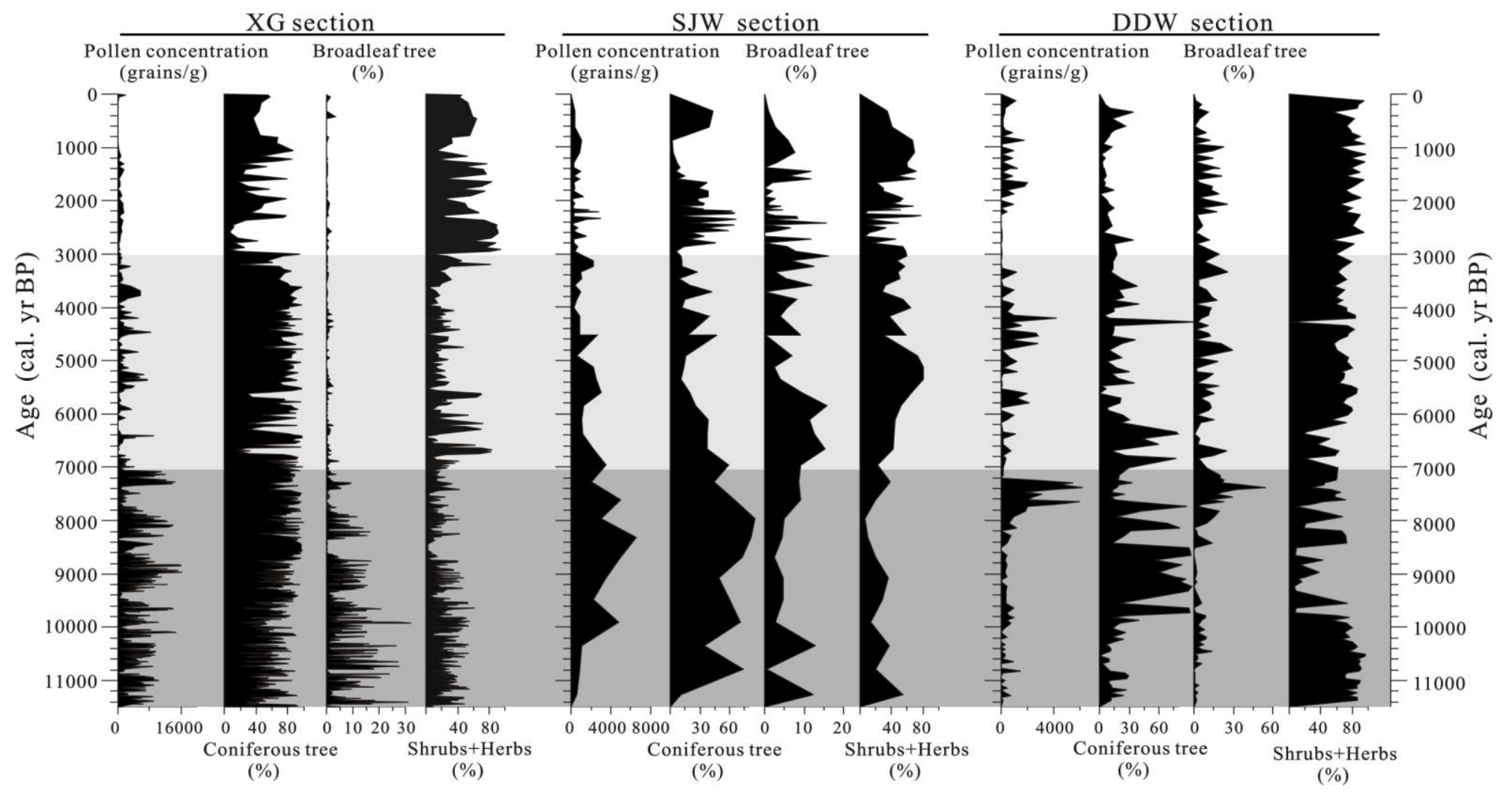


Table 1. Radiocarbon and calibrated dates of Xiaogou section

\begin{tabular}{|c|c|c|c|c|}
\hline $\begin{array}{l}\text { Laboratory } \\
\text { Number }\end{array}$ & $\begin{array}{l}\text { Depth } \\
(\mathrm{cm})\end{array}$ & $\begin{array}{c}\text { Dated } \\
\text { Material }\end{array}$ & ${ }^{14} \mathrm{C}$ age (yr BP) & $\begin{array}{c}{ }^{\mathrm{c}} \text { Calibrated }{ }^{14} \mathrm{C} \\
\text { age }(1 \varphi)(\text { cal. yr } \\
\text { BP })\end{array}$ \\
\hline${ }^{\mathrm{a}} \mathrm{AA} 64267^{\mathrm{a}}$ & $152-154$ & charcoal & $803 \pm 40$ & $682-738$ \\
\hline AA64268 & $674-675$ & charcoal & $4033 \pm 44$ & $4429-4532$ \\
\hline AA87138 & 800 & charcoal & $6088 \pm 45$ & 6886-7008 \\
\hline AA87139 & 850 & charcoal & $6186 \pm 44$ & $7013-7128$ \\
\hline AA 87140 & 900 & charcoal & $7484 \pm 39$ & $8370-8337$ \\
\hline AA87141 & 950 & charcoal & $7855 \pm 76$ & $8544-8776$ \\
\hline AA64270 & $1036-1037$ & charcoal & $6412 \pm 56$ & $7347-7418$ \\
\hline AA64272 & $1258-1259$ & charcoal & $8039 \pm 72$ & $8849-9023$ \\
\hline${ }^{\mathrm{b}}$ LUG06 45 & $1426-1428$ & bulk & $10870 \pm 98$ & $12809-12915$ \\
\hline LUG06 46 & $1636-1639$ & bulk & $9782 \pm 118$ & $11073-11354$ \\
\hline LUG06 47 & 1992-1996 & bulk & $10487 \pm 123$ & $12342-12675$ \\
\hline AA64275 & $2132-2133$ & charcoal & $9171 \pm 50$ & 10314-10392 \\
\hline LUG06 48 & $2132-2136$ & bulk & $9572 \pm 129$ & 10734-11108 \\
\hline AA64276 & $2226-2228$ & charcoal & $9292 \pm 79$ & $10377-10584$ \\
\hline LUG06 49 & $2360-2364$ & bulk & $11981 \pm 157$ & $13687-14020$ \\
\hline AA64277 & $2475-2478$ & charcoal & $9393 \pm 49$ & $10571-10689$ \\
\hline LUG06 50 & $2628-2632$ & bulk & $11259 \pm 107$ & $13064-13253$ \\
\hline AA64278 & $2674-2676$ & charcoal & $9210 \pm 110$ & $10251-10497$ \\
\hline AA64279 & $2874-2876$ & charcoal & $9807 \pm 52$ & $11196-11249$ \\
\hline LUG06 51 & 2924-2928 & bulk & $13501 \pm 162$ & $15755-16037$ \\
\hline
\end{tabular}

${ }^{a}$ AA samples: dated at NSF-AMS Facility, University of Arizona.

${ }^{\mathrm{b}}$ LUG samples: dated at MOE Key Laboratory, Lanzhou University of China.

${ }^{\mathrm{c} C}$ alibrated ages: using Calib501 (Stuiver et al., 1998). 
Table 2. Radiocarbon and calibrated dates of Haiyuan section

\begin{tabular}{ccccc}
\hline $\begin{array}{c}\text { Laboratory } \\
\text { Number }\end{array}$ & $\begin{array}{c}\text { Depth } \\
(\mathrm{cm})\end{array}$ & $\begin{array}{c}\text { Dated } \\
\text { Material }\end{array}$ & ${ }^{14} \mathrm{C}$ age $(\mathrm{yr}$ BP $)$ & $\begin{array}{c}\text { Calibrated }{ }^{14} \mathrm{C} \text { age } \\
(1 \varphi)(\mathrm{cal} . \mathrm{yr} \mathrm{BP})\end{array}$ \\
\hline AA56718 & $25-30$ & bulk & $7370 \pm 46$ & $8159-8259$ \\
AA56716 & $138-140$ & bulk & $7843 \pm 55$ & $8550-8662$ \\
AA56717 & 155 & bulk & $8006 \pm 47$ & $8860-8921$ \\
AA56721 & $460-462$ & bulk & $10405 \pm 57$ & $12126-12394$ \\
AA56723 & $530-531$ & bulk & $11007 \pm 57$ & $12875-12977$ \\
AA56724 & 630 & bulk & $10856 \pm 62$ & $12823-12880$ \\
AA56725 & 708 & bulk & $11359 \pm 59$ & $13180-13285$ \\
AA56726 & 734 & bulk & $11327 \pm 58$ & $13153-13258$ \\
AA56727 & 752 & bulk & $12216 \pm 64$ & $13995-14153$ \\
\hline
\end{tabular}


Table 3. Radiocarbon and calibrated dates of Sujiawan section

\begin{tabular}{lcccc}
\hline $\begin{array}{c}\text { Laboratory } \\
\text { Number }\end{array}$ & $\begin{array}{c}\text { Depth } \\
(\mathrm{cm})\end{array}$ & $\begin{array}{c}\text { Dated } \\
\text { Material }\end{array}$ & ${ }^{14} \mathrm{C}$ age $(\mathrm{yr} \mathrm{BP})$ & $\begin{array}{c}\text { Calibrated }{ }^{14} \mathrm{C} \text { age } \\
(1 \varphi)(\mathrm{cal} . \mathrm{yr} \mathrm{BP})\end{array}$ \\
\hline AA56728 & $80-81$ & bone & $1701 \pm 44$ & $1550-1628$ \\
${ }^{\mathrm{d} B e t a 181611}$ & $90-91$ & charcoal & $1930 \pm 40$ & $1857-1902$ \\
Beta181612 & $295-296$ & charcoal & $3730 \pm 40$ & $3991-4041$ \\
AA44885 & $305-306$ & charcoal & $3805 \pm 45$ & $4143-4249$ \\
AA56711 & $340-341$ & bulk & $4493 \pm 36$ & $5212-5283$ \\
AA44886T & $355-356$ & charcoal & $5881 \pm 59$ & $6639-6756$ \\
AA44886 & $410-411$ & charcoal & $8885 \pm 55$ & $9981-10102$ \\
AA56712 & $445-446$ & bulk & $12204 \pm 70$ & $13977-14149$ \\
\hline
\end{tabular}

${ }^{\mathrm{d}}$ Beta samples: dated at Beta Analytic Inc. 
Table 4. Radiocarbon and calibrated dates of Dadiwan section

\begin{tabular}{ccccc}
\hline $\begin{array}{c}\text { Laboratory } \\
\text { Number }\end{array}$ & $\begin{array}{c}\text { Depth } \\
(\mathrm{cm})\end{array}$ & $\begin{array}{c}\text { Dated } \\
\text { material }\end{array}$ & ${ }^{14} \mathrm{C}$ age $(\mathrm{yr} \mathrm{BP})$ & $\begin{array}{c}\text { Calibrated }{ }^{14} \mathrm{C} \text { age } \\
(1 \varphi)(\mathrm{cal} . \mathrm{yr} \mathrm{BP})\end{array}$ \\
\hline AA43792 & $131-132$ & charcoal & $5136 \pm 45$ & \\
AA44889 & $170-171$ & charcoal & $4955 \pm 44$ & $5643-5726$ \\
AA44887 & $190-191$ & charcoal & $5441 \pm 51$ & $6207-6292$ \\
AA43795 & $285-286$ & charcoal & $8771 \pm 81$ & \\
AA43796 & $300-301$ & charcoal & $8352 \pm 62$ & \\
AA49112 & $330-331$ & bulk & $8207 \pm 52$ & \\
AA43798 & $355-356$ & charcoal & $7539 \pm 49$ & $8329-8403$ \\
AA43791 & $460-461$ & charcoal & $11851 \pm 290$ & \\
AA49110 & $472-473$ & charcoal & $11190 \pm 290$ & $12860-13327$ \\
\hline
\end{tabular}

